\title{
Peacekeeping as Conflict Containment ${ }^{1}$
}

\author{
Kyle Beardsley
}

Duke University

AND

Kristian Skrede Gleditsch

University of Essex \& Peace Research Institute Oslo (PRIO)

1 A previous version of this article was presented at the 2014 Annual Meeting of the International Studies Association. We thank the panel discussant Paul F. Diehl. We are also grateful to the participants of the GUITARS workshop at Georgetown, especially our discussants Laila Wahedi and Jim Vreeland. We also thank Graeme Davies, Han Dorussen, Ismene Gizelis, Edward Newman, Sara Polo, and Andrea Ruggeri for helpful comments and suggestions, in addition to the editors of this special issue and the anonymous reviewers. We are indebted to Nigel Lo for data management assistance. Gleditsch is grateful for support from the Research Council of Norway (213535/F10) and the European Research Council (313373). 
A rich literature has developed focusing on the efficacy of peacekeeping operations (PKOs) in a temporal sense - asking whether the periods following a deployment are more peaceful or not. We know less about the efficacy of PKOs in a spatial sense. Can peacekeeping shape the geographic dispersion of particular episodes of violence? We posit that PKOs can contain conflict by decreasing the tactical advantage of mobility for the rebels, by obstructing the movement of armed actors, and by altering the ability for governments to seek and confront rebel actors. We investigate the observable implications using georeferenced conflict polygons from the Uppsala Conflict Data Program's (UCDP) Georeferenced Event Dataset (GED). Our findings confirm that peacekeeping operations tend to decrease movement in the conflict polygons, especially when robust forces are deployed and when rebel groups have strong ethnic ties. Our findings, on the one hand, imply that peacekeeping operations reduce the geographic scope of violence. On the other hand, peacekeeping operations may allow nonstate actors to gain strength and legitimacy, and thus constitute an even greater future threat to the state if some form of accord is not reached. 
The expansion of UN peacekeeping activities after the Cold War has generated considerable optimism about its ability to promote peace. Some observers have credited international peacekeeping activities as a major factor behind the observed decline of war (Goldstein 2011). Some scholarship has shown that, on average, peacekeeping does well to reduce the risk of recurrent violence (Diehl, Reifschneider, and Hensel 1996; Doyle and Sambanis 2000; Fortna 2008; Gilligan and Sergenti 2008; Walter 2002), shorten conflict durations (Beardsley 2014; Gilligan and Sergenti 2008), and attenuate the severity of hostilities (Hultman 2010; Hultman, Kathman, and Shannon 2013, 2014). Peacekeeping success, however, can be defined on even more dimensions (Diehl and Druckman 2010); and, presumably, peacekeeping missions will do better on some of these dimensions than others. Moreover, there is a great deal of variation in how well peacekeeping fares, dependent upon mission characteristics. To be sure, failures of peacekeeping to improve security remain easy to find, and studies that have taken a qualitative look across peacekeeping missions have provided an important context to aid in understanding the merits (and limitations) of peacekeeping in advancing the prospects for peace in (and between) war-torn countries (Diehl 1994; Howard 2008; Paris 2004). The quantitative literature has also found that peacekeeping is limited in improving human rights (Murdie and Davis 2010), shortening periods of violence (Gilligan and Sergenti 2008), and reducing rebel violence against civilians (Hultman 2010).

Existing work has focused on how peacekeeping promotes peace within the countries affected on a temporal dimension, assessing whether periods that follow the deployment of peacekeepers tend to be more peaceful. We have much less evidence, however, as to whether UN peacekeeping activities affect peace on a spatial dimension. Diehl and Druckman (2010) highlight the importance of thinking about the many different effects peacekeeping may have, including the geographic containment of conflict. Peacekeepers 
exist in space, and their presence plausibly affects the locations of conflict and peace, not solely their duration and severity. We lack, however, systematic assessments of how peacekeeping affects the geographic dispersion of conflict. Collier, Chauvet, and Hegre (2008) and Beardsley (2011) consider the potential for peacekeeping to diminish the spread of conflict across state borders, but existing work has not analyzed how peacekeeping impacts the mobility of conflict zones within the states where the peacekeepers are deployed.

Skepticism might be warranted in considering whether peacekeeping does much to alter the locations where armed conflict occurs, given limitations in capability and willingness to engage armed actors. Lessons from places such as Rwanda, Bosnia, Somalia, and Lebanon might suggest that PKOs will tend to stand aside and/or be withdrawn as armed actors mobilize, in order to keep peacekeepers out of the line of fire. However, Friis (2010) argues that peacekeeping and counterinsurgency $(\mathrm{COIN})$ are starting to converge. If this is the case, then we might expect peacekeeping to lead to conflict displacement or increase the movement of conflict zones, as the deployment of international forces might mimic the strengthening of government forces and cause rebel groups to fight in disparate locations as a means of survival. Still another expectation emerges when considering that peacekeeping tends to impede the movement of transnational actors responsible for the contagion of conflict across state boundaries (Beardsley 2011). PKOs appear to do well in preventing the spread of conflict across state boundaries, and it is possible that they also do well containing the spread of conflict within states.

The relationship between peacekeeping and the geographic orientation of conflict can help us better understand how peacekeeping relates to some of the underlying foundations of conflict. Recent research has emphasized the need to look at the local characteristics in conflict zones to evaluate claims about possible motives and opportunities for conflict (Buhaug and Rød 2006; Buhaug, Cederman, and Rød 2008; Cederman, Buhaug 
and Rød 2009; Cederman and Gleditsch 2009; Cederman, Weidmann, and Gleditsch 2011; Cunningham and Weidmann 2010; Hegre, Østby, and Raleigh 2009; Raleigh and Hegre 2009; Weidmann 2009, 2011; Weidmann and Ward 2010; Zhukov 2012). This developing literature has contributed to a growing understanding about the local roots of rebellion and insurgency. These existing studies, however, are limited in treating the conflict zones as fixed and invariant over the course of the conflicts. Yet, the UCDP GED data shows, significantly, that the movement of intrastate armed conflicts is pervasive. The data, described below, show: (i) on average $45 \%$ (by both mean and median) of the armed conflict areas in a given year overlap with the conflict area in the previous year, and (ii) $25 \%$ of the annual conflict areas have virtually no overlap with those in the previous year.

Conflict zones can and do change considerably over the course of the hostilities. A number of studies have considered the potential for intrastate conflict to spread between countries (Braithwaite 2010; Buhaug and Gleditsch 2008; Salehyan 2009; Salehyan and Gleditsch 2006). Moreover, some recent work has analyzed the spread of conflict event locations using more geographically disaggregated information, examining how this relates to various characteristics of conflicts and the antagonists (Beardsley, Gleditsch, and Lo ND; Schutte and Weidmann 2011; Zhukov 2012). However, to date, research has not had much to say about the role of third parties in affecting the patterns of movement in conflict areas.

Not only is the movement of conflict zones pervasive and thus an interesting phenomenon to study in its own right, but conflict movement also helps us understand other phenomena such as the humanitarian footprint of conflicts - given that many victims of intrastate violence are noncombatants - and the means by which nonstate actors survive and extract resources in the face of COIN efforts. We thus focus on conflict containment as an important yet understudied outcome of peacekeeping activity. We note, however, that containment in and of itself should not be equated with peacekeeping "success" because 
containment can in some cases be undesirable, as when it contributes to longer conflict and impunity for the actors committing atrocities or negotiating in bad faith. Diehl and Druckman (2010) also note that in many cases peacekeeping "success" in confronting armed actors can entail the movement of armed hostilities (to where peacekeepers are not deployed) and that such movement does not necessarily imply the failure of peacekeeping operations in achieving their mandated goals. We return to the potential positive and negative implications of containment below.

\section{A Motivating Example: JEM and UNAMID}

Consider, for example, the case of the African Union-United Nations Mission in Darfur (UNAMID). The Darfur conflict is a prominent case of an ongoing conflict generating calls for international responses to stop the conflict or at least reduce the level of violence. The conflict reached its peak intensity over the period 2003-2005. The period after UNAMID was set up and deployed in 2007 may have seen a lessening in the intensity of the conflict; however, fighting has continued even with UNAMID on the ground, and the violence has exceeded the conventional threshold for an armed conflict of 25 annual battle deaths as used by the Uppsala Armed Conflict Dataset. ${ }^{2}$ Of course, the fact that the fighting has continued in Darfur does not by itself imply a failure, as one could imagine that conflict would have been much worse in the absence of a peacekeeping mission. A relevant question, however, is to what extent peacekeeping has plausibly contributed to decreasing the likely geographic scope of violence in the Darfur conflict.

\footnotetext{
${ }^{2}$ For a short overview of the conflict, see de Waal, Hazlett, Davenport and Kennedy
} (2014). 
The case of the geographical spread of the attacks by the most mobile rebel movement originating from the Darfur conflict, the so-called Justice and Equality Movement (JEM) in Sudan, and its relationship with UNAMID, illustrates why this is an interesting question. JEM opposes the Omar al-Bashir government and calls for the creation of a United Regions of Sudan, with a presidency rotating among the regions. The origins of the movement appear to stem from a set of anonymously published manuscripts entitled The Black Book: Imbalance of Power and Wealth in the Sudan, criticizing the Northern Arabs' privileged status and political dominance of Sudan. According to UCDP data, JEM is considered active as of 2003, when it collaborated with the Sudan Liberation Army (SLA) on an attack against a garrison in Darfur. After the splintering of the SLA (following the 2006 Darfur Peace Agreement), JEM remained the most potent challenger of the Sudanese government.

Figure 1 displays the activities of JEM as recorded by the UCDP GED project for 2009 and 2010. The individual attacks carried out in each year are displayed as dots. We draw a polygon around the convex hull of the attacks as a measure of the geographical area of the group's activity. The polygon for the current year's activity is shown in grey (i.e., the medium shade used in the map), while the polygon for last year's activity is shown in light grey. The overlapping area between the polygons for last year's activity and the current year's activity is shown in dark grey. ${ }^{3}$

${ }^{3}$ In our analyses below, we use the size of the overlapping area as a percentage of the previous year's polygon to measure the degree to which a conflict has a consistent theater, or displays roaming. 


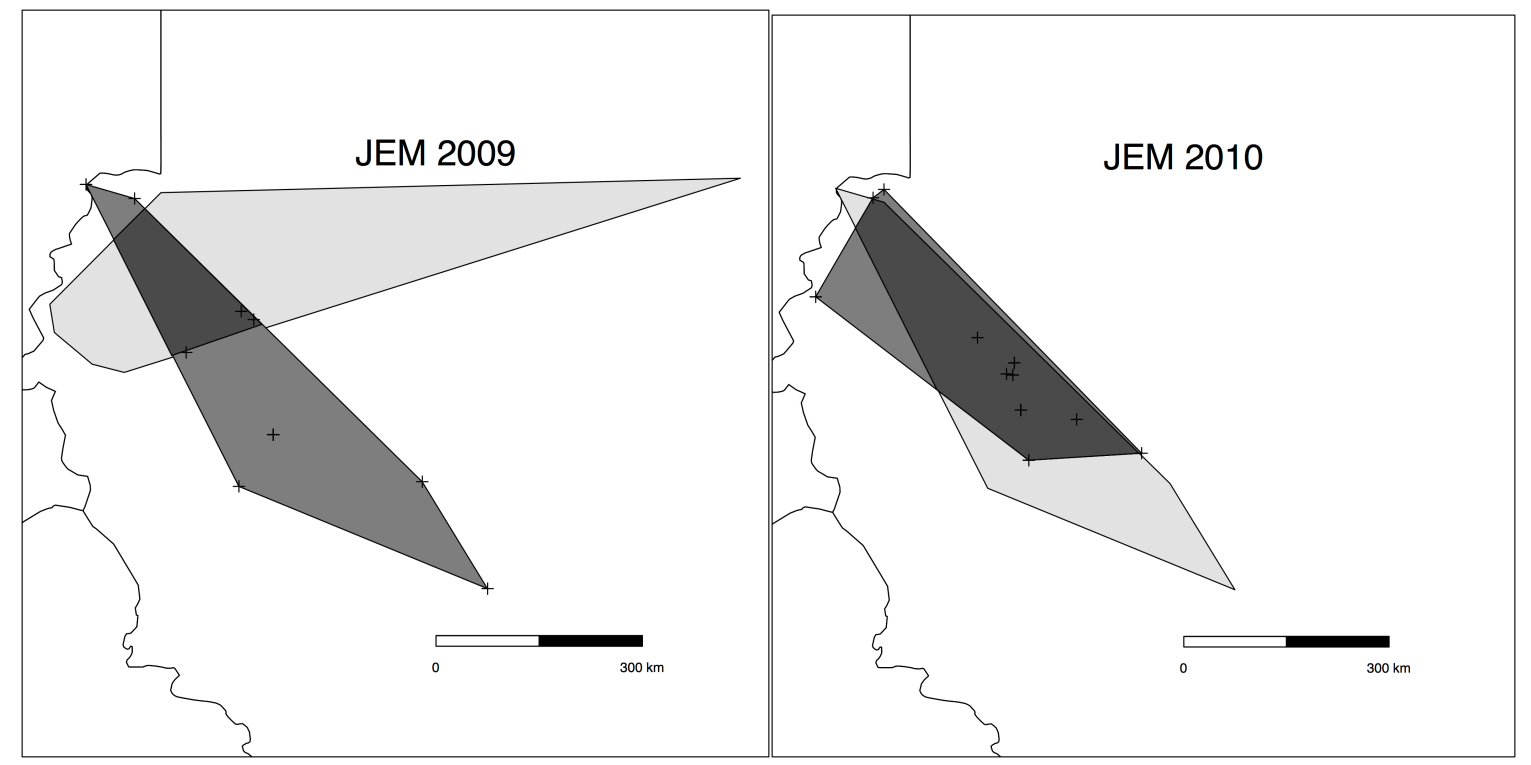

FIG 1. Sudan JEM, 2009-10

It is clear from Figure 1 that the geographic theater of fighting between JEM and Sudanese forces changed much between 2008 and 2009. In May 2008, JEM struck against Khartoum itself, and managed to temporarily control territory at the western side of the Sudanese capital before being repelled by the army. This activity pattern is consistent with JEM's declared goal of fighting the government over the entire country, and roaming is also likely spurred by JEM's inability to maintain a stronghold in North Darfur, leading to geographic displacement. While JEM's activity between 2008 and 2009 can be characterized as mobile, its fighting activity between 2009 and 2010 had much more geographic consistency.

Does the variation in conflict zone movement correlate with UNAMID activities? UNAMID condemned the 2008 attack, but it had limited ability to do anything beyond criticizing JEM and monitoring its activities. The United Nations Secretary General (UNSG) report for the relevant period (S/2008/400) indicates that the JEM attack itself disrupted UNAMID activities considerably. It is clear from a review of UNAMID's activities that they 
have carefully monitored rebel activities and engaged them politically, but there is little evidence that they directly confronted JEM, save for accidental attacks and skirmishes.

There are many reasons why peacekeepers are unlikely to act militarily against rebels. The UNAMID mandate emphasizes that the mission should support the implementation of the Darfur Peace Agreement, and "prevent the disruption of its implementation and armed attacks, and protect civilians." That is, the mandate is oriented toward prevention and protection, not toward engaging armed actors in battle. Thus, if UNAMID has helped to contain rebels and armed interactions between the rebels and the government, the effect must be through mechanisms other than direct military engagement, such as through changing JEM's likely pattern of operations and deterring military attacks on the government, or perhaps affecting the movement and tactics of the Sudanese Armed Forces.

Figure 2 illustrates the growth of UNAMID in terms of the numbers of observers and the numbers of troops. While the numbers under the mission were relatively limited in 2008 , there was a strong subsequent growth in observers and military personnel. UNAMID has had some clear successes in its political engagement, including the 2009 goodwill agreement signed between JEM and the government, and later the 2010 Doha agreement. Interestingly, we note that the year-on-year change in conflict zone movement from 2009 to 2010 is much smaller than the previous period, suggesting that the more than 15,000 UNAMID troops plausibly may have helped to geographically contain JEM activities in the latter period. 

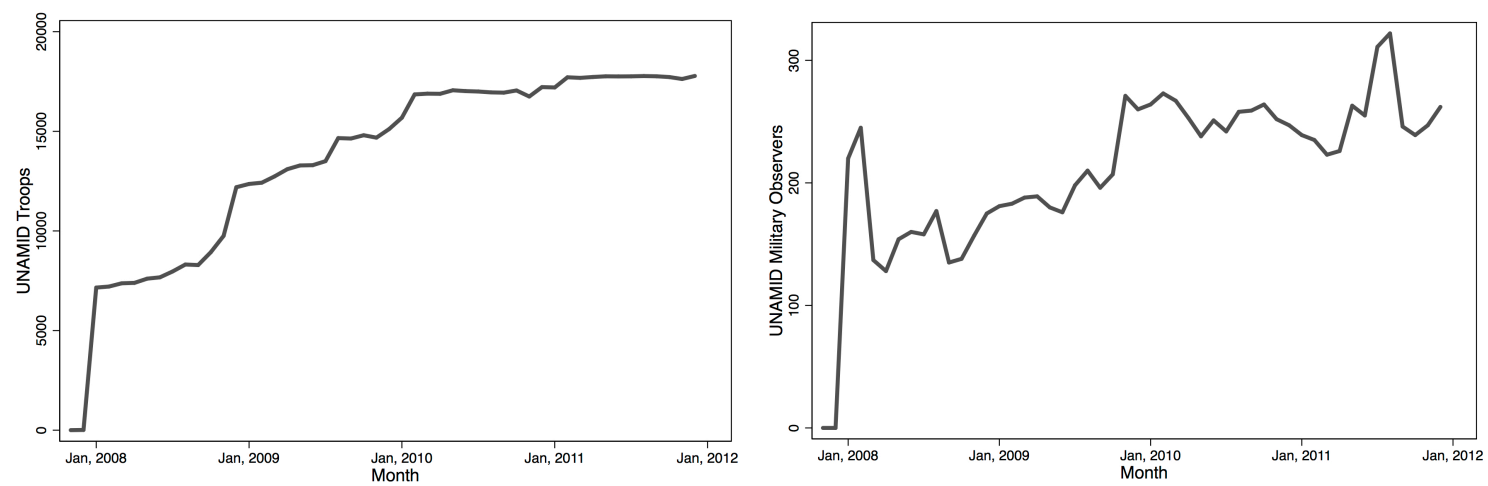

FIG 2. UNAMID Troops and Observers

Thus, we have some suggestive evidence that the growth in UNAMID goes together with a spatial confinement of JEM, countering the previous tendency to roam. However, it is difficult to conclusively establish much from this example alone since we do not observe the counterfactual of what would have happened in their absence, nor have we been very specific on the causal mechanisms and threats to validity. The impact of peacekeeping activities is thus difficult to answer without looking at a wider range of cases, where we can take advantage of variation in peacekeeping and conflict characteristics, grounded in a theory on the mechanisms whereby peacekeeping plausibly affects the movement of zones of conflict.

In what follows, we begin by laying out a theory explaining variation in the movement of conflict zones. We then consider how peacekeeping can shape those dynamics, and we argue that peacekeeping is situated for conflict containment, especially when the PKO force is large, the rebel forces are much weaker than the government forces, and the rebel group has strong local ethnic ties. We then describe our research design to empirically investigate the observable implications and report the findings. 


\section{Theory}

\section{Actor Incentives}

Before turning to how peacekeeping might affect the geographic dispersion of violence, we need to understand why conflict tends to be so mobile in the first place. We argue that, although rebels might benefit from being stationary, certain environments make it more likely that they fight in varied locations, out of both necessity and tactical choice (Beardsley, Gleditsch, and Lo ND). Starting with why rebels can benefit from more enduring or stationary conflict zones, we posit that fighting in a consistent theater and better defined home ground can enable groups to gain more local support or establish stronger control. In the same vein as Mancur Olson's $(1993 ; 2000)$ allegory of roving and stationary bandits, armed actors that are able to establish consistent hierarchy can come to rule with legitimate authority rather than through expensive brute force that is likely to face continued resistance. Applied to the intrastate conflict context, rebel groups that stay localized-and, by implication, are more likely to fight in consistent locations - are better able to compete with the state as the side with legitimate authority and win local support.

Rebels, however, often have other incentives to fight in inconsistent theaters. Fighting in diverse locations can help rebel groups evade government counterinsurgency efforts. That is, although rebel groups benefit from staying local, they are often forced to become mobile as a means to survive. Groups that are very weak relative to the government stand a high risk of simply being conclusively defeated if they try to fight the state in the same location or consistent theaters of combat. Staying mobile allows them to carry out typical guerilla tactics meant to hurt the state with less risk of complete defeat.

There is a long line of research attesting to how mobility in asymmetric warfare can help small groups defeat much stronger opponents (Arreguin-Toft 2005; Mack 1975). Small 
nonstate actors can maintain an informational advantage over the government through varying the locations of their armed activity - they are likely to have much more information about the locations of the government forces than the government forces are likely to have about their locations.

Aside from staying mobile as a means of staying viable from a position of relative weakness, sometimes rebels are fighting over control of the state, rather than the autonomy of some ethnic homeland, and thus need to take the fight to varying locations so as to secure a wider base of support. Although such guerrilla warfare by itself cannot overthrow the government, sustained fighting activity can advertise the group's presence and convert people to the rebels' cause, and in turn, help the movement grow to a point where it can eventually oppose the government. And, once the rebels have the clear upper hand, the conflict is likely to be even more mobile as they strike toward the capital or other strategic locations in the state. Moreover, when rebel groups lack strong ethnic ties to a particular group, the establishment of local hierarchy is not likely to be as beneficial as when it can more easily claim to be the champion of a well-defined segment of the population.

On the other side, the government has an incentive to prevent rebels from setting up local strongholds, from which the rebels can establish position and drum up anti-regime sentiment among their core constituency. Government counterinsurgency strategies typically advocate attacks against rebel strongholds to force rebels to flee or fight under less favorable circumstances (not of their own choosing), and also target locations crucial to territorial control, attempting to turn the civilians in rebel strongholds against the rebels (Galula 1964; Paul, Clarke, Grill, and Dunigan 2013; Valentino, Huth, and Balch-Lindsay 2004). Kalyvas (2006) discusses at length the problems that states face when they cannot penetrate strong pockets loyal to the rebellion. Especially in minority ethnic enclaves where state forces cannot well distinguish between combatants and noncombatants, states often react to an 
entrenched rebellion by resorting to indiscriminate violence or efforts to relocate the local population in order to uproot the insurgents and establish authority. Although this may be helpful from a military or logistical perspective, it is potentially politically counterproductive in that it might increase sympathy for the rebels (Kalyvas and Kocher 2009; Kocher, Pepinsky, and Kalyvas 2011; Lyall, Blair, and Imai 2013). Thus, to prevent such pockets from becoming firmly established, governments that are capable have an incentive to strike at rebel strongholds at the earliest opportunity, even if it means having to subsequently cover larger areas and displacing the conflict zones. Containment may be cheaper in the short run, but it also ensures that the rebel groups remain viable, with the opportunity to compete with the state as the legitimate sovereign of a particular territory.

The degree to which conflicts move will thus depend on the relative strength of the combatants and the potential of the rebel groups for the establishment of legitimate authority over certain pockets of the local population. Earlier work confirms that conflict zones are more mobile when rebel groups are relatively much weaker than government forces and when rebel groups do not claim to be fighting for control over an ethnic homeland (Beardsley, Gleditsch and Lo ND). This earlier work, however, does not consider the potential role that third parties can play in shaping these incentives for battles to occur in different locations. Specifically, it is unclear if peacekeeping tends to bolster the strength of the state and thus lead to an even greater spread of conflict, or if the peacekeepers might disrupt the incentives for both state and nonstate actors to fight in varied locations.

\section{Peacekeeping and Conflict Mobility}

Within this context of actor incentives (to fight in different locations or to maintain a consistent theater of warfare), we consider how peacekeeping can play a role in shaping the 
mobility of conflict. We argue that the way peacekeeping missions have operated historically, and for the most part operate currently, is much more conducive to the containment of conflict rather than its displacement. Even though Chapter VII authorizations to use force have become much more common in peacekeeping operations (see, e.g., Johansson 2009), the mandates are often oriented toward taking up observational and defensive positions rather than offensive ones. For example, after a brutal attack by JEM forces on 10 May 2008 that killed numerous civilians, UNAMID did not respond in force but simply maintained monitoring patrols and confidence-building activities (S/2008/400). Even when JEM forces restricted UNAMID access, UNAMID did not engage with force $(\mathrm{S} / 2009 / 201)$. If UN peacekeeping operations are restrained from using force against nonstate actors such as JEM, then such operations are even less willing to militarily target government forces. Although mandates authorized under Chapter VII could be formed to empower peacekeeping forces to fight government forces, the practice is almost always to have the peacekeepers present at the consent of the host government. Indeed, the 2011 role played by the United Nations Operation in Cote D'Ivoire (UNOCI), combating forces loyal to President Laurent Gbagbo, was notable because that type of action is so rare, and in that it occurred after Gbagbo had lost an election and could thus be argued to no longer be the legitimate sovereign head of state.

Similarly, the atypical nature of UN SCR 2098 (2013), which established an "intervention brigade" as part of the United Nations Organization Stabilization Mission in the Democratic Republic of Congo (MONUSCO), illustrates that peacekeeping operations may be better suited to containment than to the pursuit of armed actors. This brigade was authorized to consist of three infantry battalions, an artillery company, and a "special force and reconnaissance" company; its mandate focused on "neutralizing armed groups" through "targeted offensive operations . . . in a robust, highly mobile and versatile manner." This 
intervention brigade does resemble the type of COIN activity that Friis (2010) discusses, but it remains rare. It is clear from the language in the resolution that this type of mission is atypical, even to the point that the resolution specifically clarifies that this is not to set a precedent for peacekeeping missions to come. As such, by way of contrast, it becomes clear that almost all peacekeeping missions (including MONUSCO prior to March 2013) do not have mandates to implement offensive operations that seek out militarized engagement with armed actors. Peacekeeping, by definition, is defensive in nature. Provided that it has an effect on the movement of conflict theaters, it will tend to contain rather than displace.

If peacekeepers are not well oriented toward offensive military action, then it is doubtful that peacekeeping forces will have much of a displacement effect. Peacekeepers do not pose to rebel groups anything like the existential threat that government forces pose (which can keep weaker rebel groups on the move for survival). The limitations of military engagement, however, do not mean that peacekeepers cannot affect conflict zone movements by containing them.

We posit that peacekeeping can indeed limit the geographic movement of armed hostilities between government and rebel forces through three mechanisms. First, the monitoring that peacekeeping provides can decrease the ability for armed contingents of any side to move undetected. Even when PKOs do not involve strong mandates or a substantial number of boots on the ground, they are responsible for monitoring the activity of the armed protagonists and to report. The deployment of more resources to watch movements decreases any informational advantage that mobile actors hope to exploit. If keeping mobile becomes marginally less beneficial, then stationarity and consistency in battle location become more likely alternatives.

As a second mechanism, peacekeepers can effectively get in the way of movement, 
by being active on major road arteries and establishing protected areas. Armed actors will be hesitant to forcefully remove such obstacles for a number of reasons. By threatening peacekeeping forces, the armed actors risk a firefight with peacekeepers, who may be restrained from acting offensively but certainly can act defensively. Moreover, since many intrastate conflicts are competitions for legitimacy, actors (both state and nonstate) may find it counterproductive to offend the international community or to allow their opponent to credibly portray them as intransigent and/or uninterested in pursuing peaceful alternatives. International condemnation could very well lead toward sanctions and a denial of recognition of their claims for sovereignty.

Third, and related to the above, PKOs can decrease the willingness of government forces to use heavy-handed tactics to clear areas of rebels and their supporters. If indiscriminate violence is more likely to bring international condemnation and sanctions when done under the watch of PKOs, then states will be less likely to resort to such tactics as a means to keep rebels from establishing control of specific localities when PKOs are deployed. In these cases, the PKOs provide a type of protection, unintentional or not, behind which rebels are freer to set down strong local roots and face less need to stay mobile as a survival tactic. We return later to this potential implication: that PKOs often help protect nonstate actors from government forces.

Our argument is thus that peacekeeping forces can affect the geographic spread of intrastate conflict, primarily through containment. Again reflecting on the limitations of PKO mandates and operations, we also qualify our expectations about when containment is likely. First, and most straightforward, we expect peacekeeping missions to have greater containment effects as their force sizes increase. PKOs will be better able to monitor when they can send out more patrols. Moreover, peacekeepers will be better able to impede the progress of the armed actors when there are more personnel. Interestingly, Ruggeri, Gizelis, 
and Dorussen (2013) find that rebel cooperation with PKOs is greater with larger missions, suggesting that large PKOs could play a protective role against government pursuit of rebels and thus decrease the need for the rebels to stay mobile for survival.

Second, we expect that peacekeepers will perform considerably better in containing the hostilities between government forces and weak rebels than in containing those involving stronger rebel movements. Stronger groups are those that do not have as much need to move for survival because they can better contend against government incursions than weaker actors. This means that stronger rebel groups will not find monitoring by peacekeeping forces as great a threat to their viability. Thus, when stronger groups wish to move, the peacekeepers are less problematic. Smaller groups, however, will be affected by the additional monitoring that PKOs provide — as their ability to stay safe while moving is likely compromised (because the PKOs can substantially reduce the informational advantage that smaller groups tend to exploit by staying mobile). Moreover, Ruggeri, Gizelis, and Dorussen (2013) also find that weak rebel groups are more likely to cooperate with UN peacekeeping missions, again suggesting the possibility of a protective role in which PKOs are oriented toward reducing the incentives for weak groups to move in response to government threats.

Third, we contend that PKOs will have a greater containment effect when groups are fighting for an ethnic homeland. The extent, albeit sometimes limited, to which the peacekeepers can reduce the aggressiveness of the government forces toward the nonstate armed actors will directly reduce the movement of clashes between rebels and government as the rebels feel more protected from threats and persecution at the hands of the government. The level of aggressiveness by state forces against rebel groups fighting for ethnic homeland might be particularly high without a PKO because the rebels in these cases can blend in well with the local civilian populations and governments may need to resort to 
indiscriminate targeting in order to harm the rebel groups. If such violence in the shadow of PKO deployment is especially likely to bring unwanted international attention and sanctions, then we might observe a pronounced deterrence of such violence and thus a substantial reduction in the need for ethnically-oriented rebel movements to stay mobile when PKOs are deployed. Moreover, in ethnically oriented conflicts, PKOs are well situated to monitor and patrol consistent contested areas in the regions claimed by the rebels to be part of their homeland. In conflicts over government, not only do the rebels have incentives to move conflict zones, but peacekeeping missions are not as well suited to the monitoring of inconsistent and often unpredictable locations.

\section{Research Design}

We test these expectations on a data set of annual dyadic civil-war observations. More specifically, we use conflict dyad polygons from the UCDP GED data (Croicu and Sundberg 2012). ${ }^{4}$ We choose to use annual polygons rather than individual geographical grid cells within conflicts or shorter time periods since we lack more disaggregated information for our key explanatory variables related to peacekeeping deployments, relative rebel strength, and ethnic claims. The GED data comprise georeferenced event data of battles within armed conflicts, where an armed conflict has at least 25 battle-related fatalities per year. The current data are limited to Africa. From the individual event data, the GED data estimate georeferenced polygons, based on calculations of the convex hull of the individual battles, to

${ }^{4}$ We chose to use the GED data instead of other alternatives such as the Armed Conflict Location and Event Data (ACLED) for ease of integration of other features that pertain to UCDP armed conflicts. 
provide a definition of the battle areas in each year of active armed conflict. ${ }^{5} \mathrm{~A}$ few armed conflicts have multiple theaters of activity and thus yield multiple polygons, which we treat as separate conflict zones. We also focus only on the state-rebel violence in civil wars covered by the nonstate actor data (Cunningham, Gleditsch, and Salehyan 2009), because the scope of our theory applies to cases of rebellion against the state but not necessarily to fighting between rebel groups or cases of one-sided violence by the state against civilians. In sum, we choose each polygon of these government-rebel dyads in each year to serve as our unit of analysis. This results in 371 initial observations for analysis, covering 1990 to 2010 . Although our data are limited to the post-Cold War period, most of the peacekeeping activities in civil war have taken place after the end of the Cold War, so the period analyzed should contain the most relevant information on the differences in spatial spread between conflicts with and without peacekeeping (see, e.g. Doyle and Sambanis 2000). We provide a full list of the dyadic (state against nonstate actor) conflicts included in the analysis in an Appendix.

\section{Modeling Conflict Zone Movement}

We choose to measure the year-on-year movement in conflict zones by calculating the

5 The GED data exclude certain isolated outliers that would lead to unreasonably defined or overly large conflict polygons. Events are considered outliers for defining polygons if they alone would account for more than $20 \%$ of the area and decrease the density of the data points in the polygon by more than $20 \%$, and the events account for less than $5 \%$ of the total number of events and deaths in the conflict (Croicu and Sundberg 2012, 9). 
percentage of overlap in the current year's conflict zone area with the previous year's conflict zone area. When the current area is completely contained within the previous area, this measure equals 1 . When the current area does not intersect with the previous area, the measure equals 0 .

With a dependent variable that is bounded by 0 and 1, we estimate the regression model for proportions suggested by Papke and Wooldridge (1996), in essence a general linear model (GLM) with a logit transformation of the response. This allows us to see how the covariates affect the proportion of overlap between subsequent conflict zones, transformed along a logistic "S" curve. We report standard errors that are robust to clustering on each country, as multiple conflicts and polygons in the same country are likely to share a number of unobserved characteristics and thus have correlated errors.

\section{Explanatory and Conditioning Variables}

We choose a few different measures of the presence of a peacekeeping force in a country. ${ }^{6}$ First, we include a binary indicator of whether a peacekeeping force is present, based on the International Military Interventions (IMI) data (Pickering and Kisangani 2009). ${ }^{7}$ The

${ }^{6}$ It is important to note the limitation that we use information about peacekeeping at the country level. Future studies might use georeferenced peacekeeping information to see how the physical location of the peacekeeping contingents affects the movement of conflict zones. Such studies might consider using the PKOLED data (Ruggeri, Gizelis, and Dorussen 2013), although information is limited to only seven conflicts, and the time coverage is also sufficiently limited to prevent a simple application to our present analysis.

${ }^{7}$ See Beardsley (2011) for a description of how the IMI data were used to select out the peacekeeping events. We updated the IMI data beyond 2005 by ensuring that the end 
advantage of the IMI data over a simple list of missions that operate under the UN Department of Peacekeeping Operations (DPKO) is that the IMI data are able to capture separate regional missions. Second, we loosely disaggregate the peacekeeping information based on whether the peacekeeping force has at least 1000 military personnel deployed, or if the force has less than that. ${ }^{8}$ This essentially distinguishes robust missions from observational missions. Third, we use information from the UN DPKO to measure the maximum numbers of troops, police, and observers that were deployed in UN missions in a given year, from Kathman (2013). ${ }^{9}$ The advantage of this latter measure is that it is more precise in both the size of the mission and the function of the personnel, even though it only covers the UN missions.

Our measure of relative rebel weakness is coded in the nonstate actor data (Cunningham, Gleditsch, and Salehyan 2009) as a categorical measure of relative rebel strength, based on a number of factors including troop sizes and fighting capacity. While most intrastate conflicts involve rebels that are weaker than the government, we are interested in cases in which they are extremely disadvantaged and have to rely on flight for survival. As a result, we code a dummy variable for whether this variable indicates that the rebels are much weaker than the government. This variable, as well as all others that can change from year to year in a conflict, is lagged one year because the dependent variable is dates of the operations reflected the 2005-2010 realities, and also adding information for the missions in Chad (MINURCAT), Burundi (BINUB) and Somalia (AMISOM).

${ }^{8}$ Beardsley (2011) uses the same measure. About $25 \%$ of the observations with a peacekeeping mission have less than 1000 military personnel.

${ }^{9}$ In countries with multiple missions, we first added across the missions for each month before calculating the maximum for the year. 
movement from the previous year to the current year and there is a potential for simultaneity bias without the lags.

Rebel aims to fight for an ethnic homeland are measured based on the ACD2EPR data, which link the actors in the Uppsala Armed Conflict Data to the ethnic groups in the Ethnic Power Relations data (Cederman, Gleditsch, and Buhaug 2013; Wucherpfennig, Metternich, Cederman, and Gleditsch 2012). The specific measure that we use is a dichotomous coding of whether the rebel group makes a claim to fight for the interests of a particular ethnic group. ${ }^{10}$

\section{Control Variables}

We control for factors that are likely associated with the tendency for conflict to spread because it is possible that the UN is more likely to authorize peacekeeping missions to the countries that have a greater need for containment. In addition to relative rebel weakness and rebel aims, our earlier work has shown that outside military support can strongly affect the propensity for conflict zones to move (Beardsley, Gleditsch, and Lo ND). We thus include a measure of external support from the UCDP External Support Data (Högbladh, Pettersson, and Themnér 2011). Specifically, we use whether there was direct military participation as a warring party by external actors for the rebel side in each government-rebel dyad. We also control for the severity of the hostilities - high levels of escalation could relate to changing conflict zones, but we are explaining movement separate from levels of escalation. We specifically include the estimated number of battle deaths related to government-rebel

${ }^{10}$ The data also allow for links based on recruitment from specific ethnic groups without explicit claims, but we do not consider this here. 
fighting from the UCDP GED data. ${ }^{11}$ Since conflicts in the mountains face geographical constraints in the potential to spread, we also control for the mean elevation of the conflict polygons. Similarly, we control for the percent of the conflict-area polygons that encompass urban space, from the Global Rural-Urban Mapping Project (GRUMP) data (GRUMP 2011), because the spread of conflict is likely to play out differently in urban and rural environments. We also include the number of distinct ethnic-group homelands encompassed by the polygons, using the ethnic-group settlement polygons from the GeoEPR data (Wucherpfennig, Weidman, Girardin, Cederman, and Wimmer 2011), because ethnic fractionalization likely shapes the aims of the rebel groups while also impacting the ability for conflict to spread. The area of the country that is the primary location of the conflict is also included in the models because borders can — although they often fail in this regardimpede the movement of conflict such that larger countries simply have more real estate for conflict to diffuse.

We also control for two characteristics about the conflict zones that are important in establishing the construct validity of our dependent variable-specifically, that it is measuring battle location movements and not simply reflecting the overall size of the conflict or the number of battles. Each model includes the areas of the polygons that define the conflict zones. The size of the conflict zone affects the expected overlap in consecutive polygons, as the new area in a larger conflict will have to be much greater in order to register the same percentage overlap as smaller conflicts. ${ }^{12}$ Related, we also control for the number

${ }^{11}$ We use the natural $\log$ of this variable because a slight increase in fatalities is less likely to be meaningful in establishing the severity of violence in the bloodiest conflicts.

${ }^{12}$ We transform the conflict area variable by taking the natural log because each additional square kilometer is likely to matter much less when the conflict area is already 
of GED events used to comprise each polygon because these will affect the shape of the polygons formed and how well defined these are with respect to individual events. Polygon shape will have some bearing on the extent to which conflict polygons are likely to move in the next period, as shapes with fewer vertices are likely to be more prone to large shifts as battle locations come and go from year to year.

Finally, we control for two variables that relate to the phase of conflict because peacekeeping, almost by definition, tends to deploy during phases of conflict abatement which might also be associated with less active armed actors. So, comparing observations with peacekeeping to observations without peacekeeping risks comparing the types of phases that tend to experience peacekeeping (and that happen to experience less conflict zone movement) to those that do not typically experience peacekeeping (and that happen to involve more mobile actors). To address this potential, we control for the duration of the conflict in years and the year-on-year change in conflict area. The former directly controls for the timing of any PKOs in the lifetime of the conflict; the latter controls for whether or not the conflict has recently been winding down in scope or widening.

While such control variables attempt to reduce some concerns for endogeneity bias that would arise if the PKO deployments were a function of the potential for conflict zones to be mobile, questions of causal identification remain because of the possibility that we are missing unobserved, or indeed unobservable, processes. We thus run regression models to see if lagged movement can adequately explain peacekeeping deployments and find that it does not. We also note, following Fortna (2008), Beardsley and Schmidt (2012), Gilligan and Sergenti (2008), and Gilligan and Stedman (2003) that PKOs are more likely to deploy to the more intractable conflicts that pose the greatest threats to international stability. This 
implies that PKOs are more likely to deploy to those conflicts that are less likely to stay contained. Thus, if there is endogeneity bias, it is most likely against finding that PKOs contain conflict, making any findings that PKOs do contain all the more significant.

\section{Results}

The results from the GLM estimation confirm many of the expectations. Table 1 presents the coefficient estimates for five models. Recall that since the response here is the percentage overlap from the conflict polygon last year to the polygon in the current year, positive coefficients imply higher overlap or less movement in conflict, while negative coefficients indicate greater spatial variation from one year to the other. Model 1 uses the binary measure for a peacekeeping operation and reveals that conflict zones are more likely to have substantial overlap when peacekeeping forces are deployed. As can be seen from the positive coefficient, peacekeeping operations tend to contain intrastate armed conflict. Model 2 disaggregates the PKOs into robust and observational forces. The findings here indicate that the containment effect of peacekeeping is largely driven by the more robust forces; the coefficient for peacekeeping operations with less than 1000 military personnel has the wrong sign, while the coefficient for robust missions retains a large and statistically significant association with higher overlap and lower conflict mobility.

Model 3 uses more precise measurements of the numbers of troops, police, and observers deployed. ${ }^{13}$ Like Models 1 and 2, we see that the ability for PKOs to contain conflict is increasing in the numbers of military troops deployed. The estimated effect of

${ }^{13}$ Eleven observations are lost because we do not have deployment numbers for 1989, which are needed for the lagged values in 1990. 
observer personnel is not statistically significant, while the estimated effect of police personnel is, interestingly, statistically significant and negative. That is, more police personnel tend to be associated with greater displacement, not containment, of conflict zones.

The failure to find a positive relationship between police personnel and conflict containment may be due to the many problems with the UN's ability to facilitate policing matters during peacekeeping, an area which Durch and England $(2010,33)$ note "has faced chronic challenges." However, although police forces may not be an appropriate response to armed conflict and fail to have much effect on the activities of armed nonstate actors, it is still unexpected that the relationship should be positive. Further investigation reveals that much of the effect appears to stem from the SLM/A in Sudan in 2010, when there was no overlap in the subsequent polygons and over 5000 police deployed. Dropping this single observation alone renders the estimate for the police coefficient statistically insignificant.

Table 1. Changes in Conflict Zone Overlap

\begin{tabular}{|c|c|c|c|c|c|c|}
\hline & 1 & 2 & 3 & 4 & 5 & 6 \\
\hline \multirow[t]{2}{*}{ PKO } & $0.588 * * *$ & & & $0.437^{*}$ & 0.335 & 0.116 \\
\hline & $(0.162)$ & & & $(0.224)$ & $(0.441)$ & $(0.330)$ \\
\hline \multirow[t]{2}{*}{ Observational PKO } & & -0.0926 & & & & \\
\hline & & $(0.632)$ & & & & \\
\hline \multirow[t]{2}{*}{ Robust PKO } & & $0.744^{* * *}$ & & & & \\
\hline & & $(0.204)$ & & & & \\
\hline \multirow[t]{2}{*}{ UN troops } & & & $9.13 \mathrm{e}-05^{* * *}$ & & & \\
\hline & & & $(2.74 \mathrm{e}-05)$ & & & \\
\hline \multirow[t]{3}{*}{ UN police } & & & - & & & \\
\hline & & & $0.000553 * * *$ & & & \\
\hline & & & $(0.000204)$ & & & \\
\hline \multirow[t]{2}{*}{ UN observers } & & & 0.000770 & & & \\
\hline & & & $(0.00111)$ & & & \\
\hline \multirow[t]{2}{*}{ PKO x Rebels much weaker } & & & & $1.959 * *$ & & \\
\hline & & & & $(0.856)$ & & \\
\hline \multirow[t]{2}{*}{ PKO x Rebel-Gov force ratio } & & & & & -0.207 & \\
\hline & & & & & $(0.158)$ & \\
\hline PKO x Ethnic claim & & & & & & $1.286 * *$ \\
\hline
\end{tabular}




\begin{tabular}{|c|c|c|c|c|c|c|}
\hline Rebels much weaker, lag & $\begin{array}{l}-0.340 \\
(0.251)\end{array}$ & $\begin{array}{l}-0.309 \\
(0.252)\end{array}$ & $\begin{array}{l}-0.282 \\
(0.318)\end{array}$ & $\begin{array}{c}-0.481 * * \\
(0.222)\end{array}$ & & $\begin{array}{c}-0.476 * * \\
(0.234)\end{array}$ \\
\hline Rebel-Gov force ratio, lag, logged & & & & & $\begin{array}{c}0.0435 \\
(0.0589)\end{array}$ & \\
\hline Ext. mil. participation with rebels, lag & $\begin{array}{c}-1.068 * * * \\
(0.355)\end{array}$ & $\begin{array}{c}-1.224 * * * \\
(0.354)\end{array}$ & $\begin{array}{c}-0.742 * * \\
(0.323)\end{array}$ & $\begin{array}{c}-0.946 * * \\
(0.428)\end{array}$ & $\begin{array}{c}-1.029 * * \\
(0.471)\end{array}$ & $\begin{array}{r}-1.350 * *: \\
(0.327)\end{array}$ \\
\hline Ethnic claim & $\begin{array}{c}0.816 * * \\
(0.354)\end{array}$ & $\begin{array}{c}0.825 * * \\
(0.360)\end{array}$ & $\begin{array}{l}0.692^{*} \\
(0.363)\end{array}$ & $\begin{array}{c}0.746 * * \\
(0.361)\end{array}$ & $\begin{array}{c}0.830 * * \\
(0.417)\end{array}$ & $\begin{array}{l}0.689 * \\
(0.361)\end{array}$ \\
\hline Conflict area, lag, logged & $\begin{array}{c}0.553^{* * *} \\
(0.0788)\end{array}$ & $\begin{array}{c}0.566 * * * \\
(0.0739)\end{array}$ & $\begin{array}{c}0.576 * * * \\
(0.0800)\end{array}$ & $\begin{array}{c}0.579 * * * \\
(0.0679)\end{array}$ & $\begin{array}{c}0.588 * * * \\
(0.0837)\end{array}$ & $\begin{array}{c}0.587^{* * *} \\
(0.0747)\end{array}$ \\
\hline Change in logged conflict area & $\begin{array}{l}-0.0937^{*} \\
(0.0532)\end{array}$ & $\begin{array}{l}-0.0940 * \\
(0.0519)\end{array}$ & $\begin{array}{l}-0.109 * \\
(0.0598)\end{array}$ & $\begin{array}{l}-0.0952 * \\
(0.0563)\end{array}$ & $\begin{array}{l}-0.0709 \\
(0.0583)\end{array}$ & $\begin{array}{l}-0.105^{*} \\
(0.0591)\end{array}$ \\
\hline Number of GED events, lag & $\begin{array}{c}0.0148 * * * \\
(0.00464)\end{array}$ & $\begin{array}{c}0.0147 * * * \\
(0.00459)\end{array}$ & $\begin{array}{c}0.0144 * * * \\
(0.00457)\end{array}$ & $\begin{array}{c}0.0147 * * * \\
(0.00458)\end{array}$ & $\begin{array}{c}0.0135 * * * \\
(0.00466)\end{array}$ & $\begin{array}{r}0.0142 * * \\
(0.00399\end{array}$ \\
\hline Conflict fatalities, lag, logged & $\begin{array}{c}0.0358 \\
(0.0601)\end{array}$ & $\begin{array}{c}0.0369 \\
(0.0587)\end{array}$ & $\begin{array}{c}0.0132 \\
(0.0760)\end{array}$ & $\begin{array}{c}0.0414 \\
(0.0543)\end{array}$ & $\begin{array}{c}0.0456 \\
(0.0665)\end{array}$ & $\begin{array}{c}0.0277 \\
(0.0609)\end{array}$ \\
\hline Average elevation & $\begin{array}{c}-0.000475^{*} \\
(0.000262)\end{array}$ & $\begin{array}{c}-0.000460 * \\
(0.000269)\end{array}$ & $\begin{array}{l}-0.000472 \\
(0.000292)\end{array}$ & $\begin{array}{l}-0.000415 \\
(0.000257)\end{array}$ & $\begin{array}{c}-0.000483^{*} \\
(0.000286)\end{array}$ & $\begin{array}{r}-0.000530 \\
(0.00024 \varsigma\end{array}$ \\
\hline Pct. of area that is urban & $\begin{array}{c}4.801^{* * *} \\
(1.287)\end{array}$ & $\begin{array}{c}4.847^{* * *} \\
(1.282)\end{array}$ & $\begin{array}{c}4.563^{* * *} \\
(1.278)\end{array}$ & $\begin{array}{c}5.043^{* * *} \\
(1.237)\end{array}$ & $\begin{array}{c}4.506 * * * \\
(1.248)\end{array}$ & $\begin{array}{c}4.996^{* * *} \\
(1.189)\end{array}$ \\
\hline Number of ethnic groups & $\begin{array}{c}-0.0541 * * \\
(0.0271)\end{array}$ & $\begin{array}{l}-0.0486 * \\
(0.0277)\end{array}$ & $\begin{array}{c}-0.0533^{*} \\
(0.0293)\end{array}$ & $\begin{array}{c}-0.0673 * * \\
(0.0282)\end{array}$ & $\begin{array}{c}-0.0497 * * \\
(0.0202)\end{array}$ & $\begin{array}{r}-0.0638^{*} \\
(0.0295)\end{array}$ \\
\hline Country area & $\begin{array}{c}-0.223 * * * \\
(0.0816)\end{array}$ & $\begin{array}{c}-0.235^{* * *} \\
(0.0747)\end{array}$ & $\begin{array}{c}-0.282^{* * *} \\
(0.100)\end{array}$ & $\begin{array}{c}-0.235^{* * *} \\
(0.0833)\end{array}$ & $\begin{array}{c}-0.308 * * * \\
(0.0958)\end{array}$ & $\begin{array}{c}-0.203 * * \\
(0.0859)\end{array}$ \\
\hline Conflict duration & $\begin{array}{c}0.0263 \\
(0.0180)\end{array}$ & $\begin{array}{c}0.0218 \\
(0.0195)\end{array}$ & $\begin{array}{c}0.0202 \\
(0.0185)\end{array}$ & $\begin{array}{l}0.0322^{*} \\
(0.0179)\end{array}$ & $\begin{array}{c}0.0252 \\
(0.0210)\end{array}$ & $\begin{array}{c}0.0194 \\
(0.0166)\end{array}$ \\
\hline Constant & $\begin{array}{c}-7.163^{* * *} \\
(1.226)\end{array}$ & $\begin{array}{c}-7.237^{* * *} \\
(1.094)\end{array}$ & $\begin{array}{c}-6.515^{* * *} \\
(1.562)\end{array}$ & $\begin{array}{c}-7.434 * * * \\
(1.079)\end{array}$ & $\begin{array}{c}-6.608 * * * \\
(1.299)\end{array}$ & $\begin{array}{r}-7.719 * * \\
(1.136)\end{array}$ \\
\hline Observations & 257 & 257 & 246 & 257 & 242 & 257 \\
\hline
\end{tabular}

Standard errors in parentheses

$* \mathrm{p}<.05, * * \mathrm{p}<.025, * * * \mathrm{p}<.01$ in a one-

tailed test

Another possibility is that policing deployments closely reflect the underlying need for personnel, which is potentially a function of the conflict scope. We investigated the possibility that the positive containment findings related to troop deployments and/or negative containment findings related to police deployments are actually a product of reverse causality, where certain types of deployments are more or less likely depending on 
the propensity for movement. However, when we regressed troop and police personnel on lagged conflict movements, we found no statistically significant relationships in support of this. Table 2 present the results-Model 7 uses troop deployments and Model 8 uses police deployments as the dependent variables. We do not see evidence that police deploy to the conflicts that are quite mobile or that troops deploy to the conflicts that are less mobile.

Returning to the main results, Figure 3 shows the substantive effects (with $95 \%$ confidence intervals) of increases in troop and police personnel. Future research might better uncover why police personnel (if anything) seem to be associated with the displacement of conflict rather than its containment, and how police troops in peacekeeping can best be integrated with and complement military troops.

To see if peacekeeping tends to do better at containing weaker rebel groups, Model 4 includes an interaction term between the basic peacekeeping indicator and relative rebel weakness. The coefficient on the interaction term is statistically significant, and, when considering the constitutive terms, the interpretation is that peacekeeping has a modest containment effect when the rebel groups are not very weak, and peacekeeping does especially well to contain conflicts when the rebel groups are very weak. This estimate, however, relies on only four observations in which there is both peacekeeping and a very weak rebel group, and three of these observations come from the same conflict. As a robustness test, we use an alternative measure of relative strength, which is the ratio of rebel troop numbers to government troop numbers, based on the Non-State Actor data, supplemented with data from Wood (2010) and Correlates of War (COW) capabilities data on military personnel. ${ }^{14}$ The results are presented in Model 5 and are not robust. We thus

${ }^{14}$ We do not use this troop ration measure as our base measure because we lose a number of observations due to missing information in the UCDP Conflict Encyclopedia. 
cannot conclude with sufficient confidence that peacekeepers are better able to contain conflicts when the rebels are weak.

Table 2. PKO Deployments

\begin{tabular}{|c|c|c|}
\hline & 7: Troops & 8: Police \\
\hline \multirow[t]{2}{*}{ Conflict zone overlap, lag } & -409.9 & -355.5 \\
\hline & $(2,174)$ & (324.9) \\
\hline \multirow[t]{2}{*}{ Rebels much weaker, lag } & $-4,236^{*}$ & -656.1 \\
\hline & $(2,191)$ & $(467.4)$ \\
\hline \multirow[t]{2}{*}{ Ext. mil. participation with rebels, lag } & $-1,169$ & -496.5 \\
\hline & $(1,840)$ & $(310.0)$ \\
\hline \multirow[t]{2}{*}{ Ethnic claim } & $-1,238$ & -210.2 \\
\hline & $(1,020)$ & $(193.6)$ \\
\hline \multirow[t]{2}{*}{ Conflict area, lag, logged } & -191.3 & -1.598 \\
\hline & $(273.1)$ & (31.61) \\
\hline \multirow[t]{2}{*}{ Change in logged conflict area } & 48.05 & -1.190 \\
\hline & $(134.8)$ & (20.33) \\
\hline \multirow[t]{2}{*}{ Number of GED events, lag } & -15.28 & -2.012 \\
\hline & $(13.29)$ & $(1.625)$ \\
\hline \multirow[t]{2}{*}{ Conflict fatalities, lag, logged } & 115.7 & -1.853 \\
\hline & $(149.3)$ & (19.74) \\
\hline \multirow[t]{2}{*}{ Average elevation } & 0.659 & 0.271 \\
\hline & $(1.363)$ & $(0.243)$ \\
\hline \multirow[t]{2}{*}{ Pct. of area that is urban } & 2,505 & -600.3 \\
\hline & $(5,806)$ & $(430.7)$ \\
\hline \multirow[t]{2}{*}{ Number of ethnic groups } & -321.4 & -50.50 \\
\hline & $(225.3)$ & (49.37) \\
\hline \multirow[t]{2}{*}{ Country area } & 1,234 & 229.8 \\
\hline & $(744.2)$ & $(150.5)$ \\
\hline \multirow[t]{2}{*}{ Conflict duration } & -138.4 & -16.29 \\
\hline & $(131.8)$ & $(16.44)$ \\
\hline \multirow[t]{2}{*}{ Constant } & $-8,335$ & $-2,216$ \\
\hline & $(9,126)$ & $(1,767)$ \\
\hline Observations & 194 & 194 \\
\hline
\end{tabular}

Standard errors in parentheses

${ }^{*} p<.05,{ }^{* *} p<.025, * * * p<.01$ in a one-tailed test 

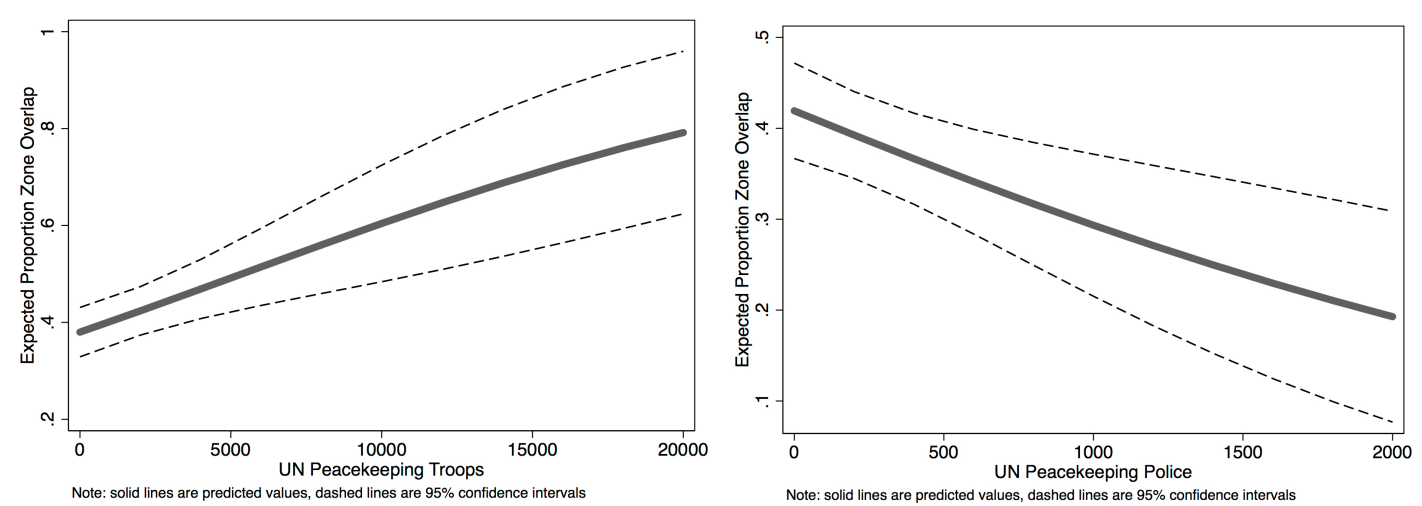

FIG 3. Containment and Displacement from UN PKO Troop and Police Deployments

Model 6 includes an interaction term between the basic peacekeeping indicator and whether the relevant rebel group has claimed to be fighting for a specific ethnic group. We expected peacekeeping to excel at containing such ethnically-oriented conflicts if the peacekeepers are able to reduce the incentives of the government forces to push the rebels out of consolidated locations. The findings confirm this expectation, as the interaction term is positive and statistically significant while the constitutive PKO term is statistically insignificant. Peacekeeping has more success containing conflicts fought against rebel groups claiming to be fighting for their ethnic homeland. Figure 4 shows the substantive effects (with 95\% confidence intervals). We observe that the level of mobility in conflict zones is similar with and without peacekeeping for the conflicts in which the rebel groups do not make an ethnic claim. When they do, the conflict zones are more likely to be contained in the presence of a PKO. 


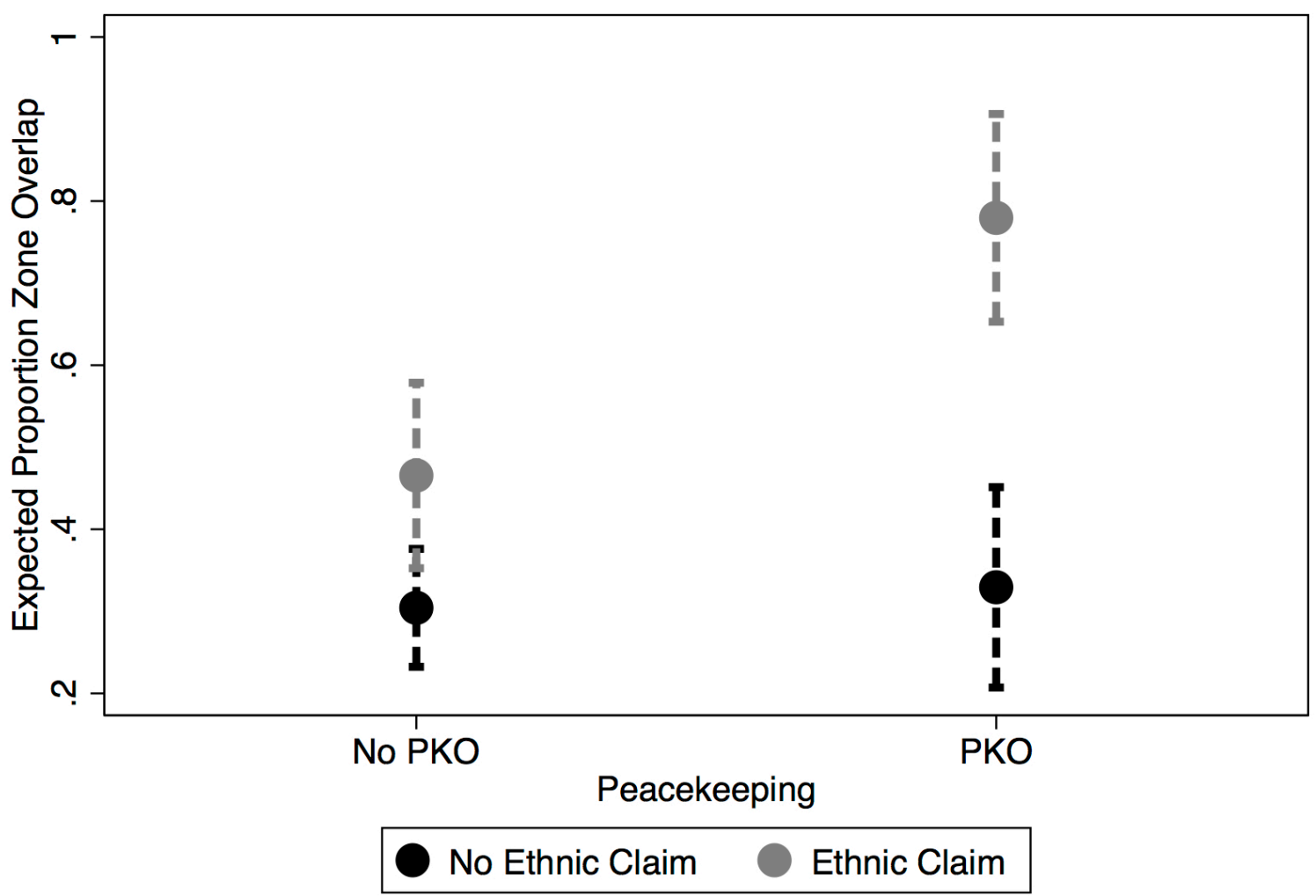

Note: Predicted values with $95 \%$ confidence intervals

FIG 4. PKO Containment Effects, by Ethnic Claims

\section{Discussion}

This paper has assessed the effects of peacekeeping operations on the year-on-year variation in intrastate armed conflict zone movement. The findings confirm that peacekeeping missions are best situated toward the containment of conflict. Moreover, the containment effects are strongest when the peacekeeping missions are robust in troop strength and when the rebel groups have war aims closely related to the fighting over an ethnic homeland.

It is telling that larger missions, especially when there are many troops, have the starkest containment effect, while observers and police numbers do not associate strongly with containment. It appears that the mechanisms by which PKOs contain conflict are much 
more related to impeding armed-actor movement and deterring government forces from uprooting rebel groups than to the reduction of informational advantages through monitoring. That observers especially do not have a strong containment effect indicates that simply keeping an eye on the actors is not sufficient to change the spatial patterns of violence. Boots on the ground are needed to occupy space, obstruct actor movements, and perhaps maintain a credible enforcement threat.

More generally, one implication of our theory is that peacekeeping may be providing cover for rebel groups, which will seize upon the opportunity to gain strength and legitimacy while under the protection of international involvement. This is especially the case for those fighting for an ethnic homeland. Although most PKOs have some nominal government consent to their deployment, they can restrict major government hostilities from targeting rebel groups, which are often embedded within civilian communities. This can create a moral hazard in which the rebels take advantage of their relative security to gain in strength, sometimes through coercive means. Hultman (2010) finds that peace operations can actually increase rebel one-sided violence unless there are specific mandates to protect civilians. This supports the claim that PKOs can provide cover for rebel groups, although the implications for robust missions are more nuanced. More robust missions may help contain conflict and provide space for rebels to avoid the sting of government pursuit, but they can also limit civilian abuse at the hands of the rebels (Hultman, Kathman, and Shannon 2013). Related, Greig and Diehl (2005) find that peacekeeping operations can decrease the incentives for actors to reach a sustainable settlement, in part because the costs of conflict are quite bearable while peacekeepers are in place. We similarly contend that peacekeeping might lead to the unintended, although often foreseen, consequence of entrenching the positions of the nonstate armed actors.

This brings us back to the question of whether conflict containment is a useful metric 
for peacekeeping success (Diehl and Druckman 2010). From the standpoint of desiring peacekeeping to promote international stability, conflict containment can be desirable, especially in the short run. In the long run, however, it is possible that the protection of nonstate actors could allow intrastate struggles to fester. From the standpoint of desiring peacekeeping to reduce the humanitarian footprint of civil war, containment also sometimes faces a stark trade-off. The protection of some nonstate actors could place members of the local population, especially those loyal to the government, in the areas controlled by rebel groups at greater risk for abuse.

Understanding that conflict containment is a likely outcome from peacekeeping, even if not a clear objective that would alone define success, does shed light on how to maximize the desired objectives. In terms of pursuing lasting stability, it is important that the international community enhances the incentives for diplomatic initiatives to move toward more permanent resolution, even and especially while peacekeepers are deployed and violence is temporarily muted. Global and regional actors with leverage over the parties must continue to move peace processes forward while peacekeepers bolster the security environment. In terms of improving the humanitarian dimensions of conflict, it is important that sufficient personnel are deployed to prevent armed actors from abusing noncombatants while under the cover of a peacekeeping mission. Our findings, combined with those from Hultman (2010) and Hultman, Kathman, and Shannon (2013), suggest that undercommitted peacekeeping can endanger local populations, while more robust peacekeeping can both contain violence and protect those under control of the armed actors. 


\section{References}

Arreguin-Toft, Ivan. 2005. How the Weak Win Wars: A Theory of Asymmetric Conflict. Cambridge: Cambridge University Press.

Beardsley, Kyle. 2011. "Peacekeeping and the Contagion of Armed Conflict." Journal of Politics 73(4):1051-1064.

Beardsley, Kyle C. 2014. "The UN at the Peacemaking--Peacebuilding Nexus.” Conflict Management and Peace Science 30(4):369-386.

Beardsley, Kyle, and Holger Schmidt. 2012. "Following the Flag or Following the Charter? Examining the Determinants of UN Involvement in International Crises, 1945-2002.” International Studies Quarterly 56(1):33-49.

Beardsley, Kyle, Kristian Skrede Gleditsch, and Nigel Lo. ND. "Roving Bandits? The Geographical Evolution of African Armed Conflicts." International Studies Quarterly TBA:TBA.

Braithwaite, Alex. 2010. "Resisting Infection: How State Capacity Conditions Conflict Contagion." Journal of Peace Research 47(3):311-319.

Buhaug, Halvard, and Jan Ketil Rød. 2006. "Local Determinants of African Civil Wars, 1970-2001.” Political Geography 25(3):315-335.

Buhaug, Halvard, and Kristian Skrede Gleditsch. 2008. "Contagion or Confusion? Why Conflicts Cluster in Space.” International Studies Quarterly 52(2):215-233.

Buhaug, Halvard, Lars-Erik Cederman, and Jan Ketil Rød. 2008. "Disaggregating 
EthnoNationalist Civil Wars: A Dyadic Test of Exclusion Theory.” International Organization 62(3):531-551.

Cederman, Lars-Erik, Halvard Buhaug, and Jan Ketil Rød. 2009. "Ethno-Nationalist Dyads and Civil War: A GIS-Based Analysis." Journal of Conflict Resolution 53(4):496-525.

Cederman, Lars Erik, and Kristian Skrede Gleditsch. 2009. "Special Issue on 'Disaggregating Civil War'.’ Journal of Conflict Resolution 53(4):487-495.

Cederman, Lars-Erik, Kristian Skrede Gleditsch, and Halvard Buhaug. 2013. Inequality, Grievances, and Civil War. New York: Cambridge University Press.

Cederman, Lars-Erik, Nils Weidmann, and Kristian Skrede Gleditsch. 2011. "Horizontal Inequalities and Ethno-nationalist Civil War: A Global Comparison." American Political Science Review 105(3):478-495.

Collier, Paul, Lisa Chauvet, and Haavard Hegre. 2008. "The Security Challenge in Conflict-Prone Countries.” Copenhagen Consensus 2008 April.

Croicu, Mihai Catalin, and Ralph Sundberg. 2012. UCDP GED Conflict Polygons Dataset Codebook version 1.1-2011. Department of Peace and Conflict Research, Uppsala University.

Cunningham, David, Kristian Skrede Gleditsch, and Idean Salehyan. 2009. "It Takes Two: A Dyadic Analysis of Civil War Duration and Outcome.” Journal of Conflict Resolution 53(4):570-597.

Cunningham, Kathleen Gallagher, and Nils B. Weidmann. 2010. "Shared Space: Ethnic Groups, State Accommodation, and Localized Conflict." International Studies 
Quarterly 54(4):1035-1054.

de Waal, Alex, Chad Hazlett, Christian Davenport, and Joshua Kennedy. 2014. "The Epidemiology of Lethal Violence in Darfur: Using Micro-data to Explore Complex Patterns of Ongoing Armed Conflict." Social Science and Medicine TBA: in press.

Diehl, Paul F. 1994. International Peacekeeping. Baltimore, MD: Johns Hopkins University Press.

Diehl, Paul F. and Daniel Druckman. 2010. Evaluating Peace Operations. Boulder, CO: Lynne Rienner Publishers.

Diehl, Paul F., Jennifer Reifschneider, and Paul R. Hensel. 1996. "United Nations Intervention and Recurring Conflict.” Internal Organization 50(4):683-700.

Doyle, Michael W. and Nicholas Sambanis. 2000. "International Peacebuilding: A Theoretical and Quantitative Analysis." American Political Science Review 94(4):779-801.

Durch, William J. and Madeleine L. England. 2010. Enhancing United Nations Capacity to Support Post-Conflict Policing and the Rule of Law. Technical report Stimson Center Report 63, Washington, DC.

Fortna, Virginia Page. 2008. Does Peacekeeping Work? Shaping Belligerents' Choices after Civil War. Princeton, NJ: Princeton University Press.

Friis, Karsten M. 2010. "Peacekeeping and Counter-insurgency: Two of a Kind?" International Peacekeeping 17(1):49-66.

Galula, David. 1964. Counterinsurgency Warfare: Theory and Practice. Wesport, CT: Praeger. 
Gilligan, Michael J. and Ernest J. Sergenti. 2008. "Do UN Interventions Cause Peace? Using Matching to Improve Causal Inference." Quarterly Journal of Political Science 3(1):89-122.

Gilligan, Michael and Stephen John Stedman. 2003. "Where Do the Peacekeepers Go?" International Studies Review 5(4):37-54.

Goldstein, Joshua S. 2011. Winning the War on War. Hialeah, FL: Dutton.

Greig, J. Michael and Paul F. Diehl. 2005. "The Peacekeeping-Peacemaking Dilemma." International Studies Quarterly 49(4):621-646.

GRUMP. 2011. Global Rural-Urban Mapping Project, Version 1 (GRUMPv1): Urban Extents Grid. Palisades, NY: NASA Socioeconomic Data and Applications Center (SEDAC), Center for International Earth Science Information Network (CIESIN), Columbia University; International Food Policy Research Institute (IFPRI), the World Bank, and the Centro Internacional de Agricultura Tropical (CIAT). http://sedac.ciesin.columbia.edu/data/set/grump-v1-urban-extents. Accessed 4 July 2012.

Hegre, Håvard, Gudrun Østby, and Clionadh Raleigh. 2009. "Poverty and Civil War Events: A Disaggregated Study of Liberia." Journal of Conflict Resolution 53(4):598-623.

Högbladh, Stina, Therése Pettersson, and Lotta Themnér. 2011. "External Support in Armed Conflict 1975-2009: Presenting New Data." Presented at the 52nd Annual International Studies Association Convention, Montreal, Canada.

Howard, Lise Morjé. 2008. UN Peacekeeping in Civil Wars. Cambridge: Cambridge University Press. 
Hultman, Lisa. 2010. "Keeping Peace or Spurring Violence? Unintended Effects of Peace Operations on Violence Against Civilians." Civil Wars 12(1-2):29-46.

Hultman, Lisa, Jacob Kathman, and Megan Shannon. 2013. "United Nations Peacekeeping and Civilian Protection in Civil War." American Journal of Political Science 57(4):875-891.

Hultman, Lisa, Jacob Kathman, and Megan Shannon. 2014. "Beyond Keeping Peace: United Nations Effectiveness in the Midst of Fighting." American Political Science Review 108(4): TBA.

Johansson, Patrik. 2009. "The Humdrum Use of Ultimate Authority: Defining and Analysing Chapter VII Resolutions." Nordic Journal of International Law $78(3): 309-342$.

Kalyvas, Stathis. 2006. The Logic of Violence in Civil War. New York: Cambridge University Press.

Kalyvas, Stathis N. and Matthew Adam Kocher. 2009. “The Dynamics of Violence in Vietnam: An Analysis of the Hamlet Evaluation System (HES)." Journal of Peace Research 46(3):335-355.

Kathman, Jacob D. 2013. "United Nations Peacekeeping Personnel Commitments, 1990-2011." Conflict Management and Peace Science 30(5):532-549.

Kocher, Matthew Adam, Thomas B. Pepinsky, and Stathis N. Kalyvas. 2011. "Aerial Bombing and Counterinsurgency in the Vietnam War." American Journal of Political Science 55(2):201-218.

Lyall, Jason, Graeme Blair, and Kosuke Imai. 2013. "Explaining Support for 
Combatants during Wartime: A Survey Experiment in Afghanistan." American Political Science Review 107(4):679-705.

Mack, Andrew. 1975. "Why Big Nations Lose Small Wars: The Politics of Asymmetric Conflict.” World Politics 27(2):175-200.

Murdie, Amanda and David R. Davis. 2010. "Problematic Potential: The Human Rights Consequences of Peacekeeping Interventions in Civil Wars." Human Rights Quarterly 32(1):49-72.

Olson, Mancur. 1993. "Democracy, Dictatorship, and Development." American Political Science Review 87(3):567-576.

Olson, Mancur. 2000. Power and Prosperity. New York: Basic Books.

Papke, Leslie E. and Jeffrey M. Wooldridge. 1996. “"Econometric Methods for Fractional Response Variables with an Application to 401(K) Plan Participation Rates." Journal of Applied Econometrics 11(6):619-632.

Paris, Roland. 2004. At War's End: Building Peace After Civil Conflict. Cambridge and New York: Cambridge University Press.

Paul, Christopher, Colin P. Clarke, Beth Grill, and Molly Dunigan. 2013. Paths to Victory: Lessons from Modern Insurgencies. Santa Monica, CA: Rand.

Pickering, Jeffrey and Emizet F. Kisangani. 2009. "The International Military Intervention Dataset: An Updated Resource for Conflict Scholars." Journal of Peace Research 46(4):589-599.

Raleigh, Clionadh and Håvard Hegre. 2009. "Population Size, Concentration, and Civil War: A Geographically Disaggregated Analysis.” Political Geography 28(4):224 
238.

Ruggeri, Andrea, Theodora-Ismene Gizelis, and Han Dorussen. 2013. "Managing Mistrust An Analysis of Cooperation with UN Peacekeeping in Africa." Journal of Conflict Resolution 57(3):387-409.

Salehyan, Idean. 2009. Rebels without Borders. Ithaca, NY: Cornell University Press.

Salehyan, Idean and Kristian Skrede Gleditsch. 2006. "Refugees and the Spread of Civil War.” International Organization 60(2):335-366.

Schutte, Sebastian and Nils B. Weidmann. 2011. "Diffusion Patterns of Violence in Civil Wars.” Political Geography 30(3):143-152.

Valentino, Benjamin, Paul Huth, and Dylan Balch-Lindsay. 2004. "Draining the Sea: Mass Killing and Guerrilla Warfare.” International Organization 58(2):375-407.

Walter, Barbara F. 2002. Committing to Peace: The Successful Settlement of Civil Wars. Princeton, NJ: Princeton University Press.

Weidmann, Nils B. 2009. "Geography as Motivation and Opportunity." Journal of Conflict Resolution 53(4):526-543.

Weidmann, Nils B. 2011. "Violence from above or from below? The Role of Ethnicity in Bosnia's Civil War.” Journal of Politics 73(4):1178-1190.

Weidmann, Nils B. and Michael D. Ward. 2010. "Predicting Conflict in Space and Time." Journal of Conflict Resolution 54(6):883-901.

Wood, Reed M. 2010. "Rebel Capability and Strategic Violence against Civilians." Journal of Peace Research 47(5):601-614. 
Wucherpfennig, Julian, Nils B. Weidman, Luc Girardin, Lars-Erik Cederman, and Andreas Wimmer. 2011. "Politically Relevant Ethnic Groups across Space and Time: Introducing the Geo-EPR Dataset.” Conflict Management and Peace Science 28(5):423-437.

Wucherpfennig, Julian, Nils Metternich, Lars-Erik Cederman, and Kristian Skrede Gleditsch. 2012. "Ethnicity, the State, and the Duration of Civil Wars." World Politics 64(1):79-115.

Zhukov, Yuri M. 2012. "Roads and the Diffusion of Insurgent Violence: The Logistics of Conflict in Russia's North Caucasus.” Political Geography 31(3):144-156. 


\section{Appendix}

Table 3. Lists of Conflicts Included

Government of Algeria - AIS

Government of Algeria - Takfir wa'l Hijra

Government of Algeria - GIA

Government of Algeria - AQIM

Government of Angola - UNITA

Government of Burundi - Palipehutu

Government of Burundi - CNDD

Government of Burundi - Frolina

Government of Burundi - CNDD-FDD

Government of Burundi - Palipehutu-FNL

Government of Central African Republic - Military faction (Forces of AndrÚ Kolingba)

Government of Chad - MOSANAT

Government of Chad - Islamic Legion

Government of Chad - CSNPD

Government of Chad - CNR

Government of Chad - MPS

Government of Chad - FNT

Government of Chad - MDD

Government of Chad - FARF

Government of Chad - MDJT

Government of Comoros - MPA/Republic of Anjouan

Government of the Republic of Congo - Ninjas

Government of the Republic of Congo - Cocoyes

Government of the Republic of Congo - Ntsiloulous

Government of Democratic Republic of Congo (Zaire) - AFDL

Government of Democratic Republic of Congo (Zaire) - RCD

Government of Democratic Republic of Congo (Zaire) - MLC

Government of Djibouti - FRUD

Government of Djibouti - FRUD- AD

Government of Ethiopia - EPRDF

Government of Ethiopia - Military faction (forces of Amsha Desta and Merid Negusie)

Government of Ethiopia - EPLF

Government of Ethiopia - ONLF

Government of Ethiopia - OLF

Government of Guinea - RFDG

Government of Guinea-Bissau - MJCDPJ

Government of Ivory Coast - MPCI

Government of Ivory Coast - MPIGO

Government of Lesotho - Military faction

Government of Liberia - NPFL

Government of Liberia - INPFL

Government of Liberia - LURD

Government of Mali - MPA

Government of Mali - FIAA

Government of Morocco - POLISARIO

Government of Mozambique - RENAMO

Government of Niger - CRA

Government of Niger - FDR

Government of Rwanda - FPR 
Government of Rwanda - FDLR

Government of Senegal - MFDC

Government of Sierra Leone - RUF

Government of Sierra Leone - AFRC

Government of Sierra Leone - Kamajors

Government of Uganda - UPA

Government of Uganda - LRA

Government of Uganda - WNBF

Government of Uganda - ADF

Government of Comoros - Presidential Guard

Government of the Republic of Congo - Cobras

Government of Angola - FLEC-FAC

Government of Angola - FLEC-R

Government of Somalia - SNM

Government of Somalia - SPM

Government of Somalia - USC

Government of Somalia - USC/SNA

Government of Somalia - SRRC

Government of Egypt - al-Gama'a al-Islamiyya

Government of Ivory Coast - MJP

Government of Ethiopia - AIAI

Government of Central African Republic - Forces of Francois Bozize

Government of Liberia - MODEL

Government of United States of America - al-Qaida

Government of Uganda - UNRF II

Government of Sudan - SLM/A

Government of Sudan - JEM

Government of Eritrea - EIJM-AS

Government of Ivory Coast - FN

Government of Nigeria - Ahlul Sunnah Jamaa

Government of Chad - FUCD

Government of Nigeria - NDPVF

Government of Central African Republic - UFDR

Government of Sudan - NRF

Government of Sudan - SLA/MM

Government of Somalia - ARS/UIC

Government of Chad - RAFD

Government of Chad - UFDD

Government of Sudan - SPLM/A

Government of Sudan - NDA

Government of Democratic Republic of Congo (Zaire) - CNDP

Government of Sudan - SLM/A-Unity

Government of Mali - ATNMC

Government of Democratic Republic of Congo (Zaire) - BDK

Government of Sierra Leone - WSB

Government of Niger - MNJ

Government of Niger - FLAA

Government of Niger - UFRA

Government of Chad - AN

Government of Somalia - Al-Shabaab

Government of Somalia - Harakat Ras Kamboni

Government of Chad - Military faction (forces of Maldoum Bada Abbas)

Government of Central African Republic - CPJP

Government of Chad - UFR

Government of Nigeria - Boko Haram

Government of Somalia - Hizbul-Islam

Government of Mauritania - AQIM

Government of Chad - FPRN

Government of Sudan - Forces of George Athor 